\title{
EFEK PEMASARAN DAN PERAN KELUARGA DALAM PEMBENTUKAN
}

\author{
EKUITAS MEREK \\ Siane Ivana Hartanto / M.F. Shellyana Junaedi \\ Program Studi Magister Manajemen \\ Program Pascasarjana \\ Universitas Atma Jaya Yogyakarta
}

\begin{abstract}
Abstraksi
Penelitian ini bertujuan untuk mengetahui apakah iklan, dan keluarga berpengaruh dalam membentuk kesadaran merek dan asosiasi merek, dan bagaimana iklan, promosi harga, dan keluarga berpengaruh dalam membentuk persepsi kualitas. Kesadaran merek, asosiasi merek, dan persepsi kualitas juga akan diuji pengaruhnya secara langsung dan tidak langsung terhadap ekuitas merek melalui loyalitas merek. Penelitian ini dilakukan di DIY dimana respondennya adalah mahasiswa.

Penelitian ini menggunakan metode kuantitatif dengan membagikan kuesioner kepada 200 responden. Teknik pengumpulan data dengan metode purposive sampling. Teknik pengolahan data menggunakan regresi linier sederhana dan regresi linier berganda.

Hasil penelitian menunjukkan bahwa iklan dan keluarga signifikan berpengaruh secara positif terhadap kesadaran merek, namun hanya keluarga yang signifikan berpengaruh terhadap asosiasi merek. Iklan, keluarga, dan harga juga terbukti berpengaruh signifikan terhadap persepsi kualitas. Kesadaran merek, asosiasi merek, dan persepsi kualitas berpengaruh signifikan secara langsung dan tidak langsung pada ekuitas merek melalui loyalitas merek.
\end{abstract}

Kata kunci : iklan, keluarga, harga, promosi harga, kesadaran merek, asosiasi merek, persepsi kualitas, loyalitas merek, ekuitas merek, efek mediasi.

\section{Pendahuluan}

Perkembangan dunia yang begitu cepat dapat dilihat dari berbagai bidang, salah satunya yaitu melalui perkembangan teknologi. Ceruk pasar di bidang teknologi semakin berkembang pesat di era globalisasi ini dan keadaan tersebut memunculkan persaingan yang ketat antar perusahaan domestik maupun dengan perusahaan asing. 
Persaingan ini akan semakin mengarahkan sistem perekonomian Indonesia ke mekanisme pasar yang memposisikan pemasar untuk selalu mengembangkan dan merebut pangsa pasar. Salah satu aset untuk mencapai keadaan tersebut adalah dengan merek. Merek menurut Aaker (1997:9) adalah nama dan atau simbol yang bersifat membedakan (seperti logo, cap, atau kemasan) dengan maksud mengidentifikasi barang atau jasa dari seorang atau kelompok penjual tertentu, dengan demikian merek yang baik adalah merek yang dapat dengan mudah membedakan dirinya dengan pesaing dan memiliki ekuitas yang kuat.

Ekuitas merek dalam Kotler \& Keller (2012: 265) adalah adalah nilai tambah yang melekat pada produk dan jasa, yang dapat tercermin dalam cara konsumen berpikir, merasa, dan bertindak sehubungan dengan merek, serta dalam harga, pangsa pasar, dan profitabilitas merek. Kotler dan Keller (2012: 266) juga menyatakan, bahwa jika ekuitas mereknya baik, maka konsumen akan bereaksi positif terhadap produk dan pemasarannya ketika mengidentifikasi merek, sebaliknya konsumen dapat bereaksi negatif dan bereaksi kurang menguntungkan terhadap produk dan pemasarannya jika ekuitas mereknya tidak baik. Hal ini menjadikan ekuitas merek sangatlah penting dan harus berusaha untuk terus ditingkatkan.

Menyadari fenomena persaingan yang semakin ketat menuntut suatu merek harus dapat dengan mudah membedakan dirinya dengan para kompetitor dan terus meningkatkan ekuitas merek yang dimiliki. Dengan mengadaptasi kerangka penelitian yang terdapat dalam penelitian dari Gil, et al. (2007) yang berjudul Family as a Source of Consumer-based Brand Equity, penelitian ini akan mencoba menganalisa bagaimana pengaruh iklan, keluarga, harga dan promosi harga penjualan dalam pembentukan ekuitas merek, dan pengaruh antara kesadaran merek, asosiasi merek, loyalitas merek, dan persepsi kualitas dalam pembentukan ekuitas merek. 


\section{Tujuan Penelitian}

Tujuan dari penelitian ini antara lain berdasarkan rumusan masalah yang telah disusun adalah untuk menganalisis pengaruh belanja iklan, informasi yang diberikan oleh keluarga mengenai suatu merek terhadap kesadaran merek, asosiasi merek, dan persepsi kualitas merek. Pengaruh harga dan promosi harga terhadap persepsi kualitas merek juga akan dianalisis. Melalui penelitian ini juga akan menganalisis pengaruh secara langsung dan tidak langsung dari kesadaran merek, asosiasi merek, dan persepsi kualitas merek terhadap ekuitas merek yang dimediasi oleh loyalitas merek. Tujuan lebih lanjut dari penelitian ini adalah untuk menganalisis pengaruh loyalitas merek terhadap ekuitas merek.

\section{Efek Pemasaran dan Keluarga pada Dimensi Ekuitas Merek}

Perusahaan dapat menciptakan ekuitas merek melalui tindakan pemasaran pada merek. Dalam pengertian ini, Keller dalam Gil, et al. (2007) mengemukakan bahwa ekuitas merek harus dikelola dari waktu ke waktu oleh penyesuaian yang baik yang mendukung program pemasaran. Gil, et al. (2007:190) dalam penelitiannya menyelidiki persepsi konsumen dari tiga elemen pemasaran: iklan, harga, dan promosi harga penjualan untuk dimasukkan dalam model penelitiannya. Variabel ini memang tidak mencakup bidang variabel pemasaran sepenuhnya, namun mereka mewakili tipikal tindakan pemasaran dan pengaruhnya terhadap ekuitas merek yang telah dipelajari sebelumnya (Yoo et al. dalam Gil, et al. 2007). Dimensi kesadaran merek merupakan hasil dari kontak individu yang terlalu lama dengan merek (Keller dalam Gil, et al. 2007). Semakin intensif kampanye iklan, semakin banyak konsumen terkena merek. Advertising recall sebagai dasar untuk mencapai kesadaran merek berkaitan secara positif dengan kekuatan belanja iklan (Deighton; Hoyer dan Brown dalam Gil, et al. 2007). Belanja iklan pada merek akan meningkatkan cakupan dan pengulangan pesan iklan, dan sebagai konsekuensinya, tingkat kesadaran yang lebih tinggi akan diperoleh untuk merek. Secara umum, CobbWalgren et al. dalam Gil, et al. (2007) menemukan hubungan positif antara jumlah 
yang dibelanjakan untuk iklan dan ekuitas merek dan dimensi. Belanja iklan yang dirasakan oleh konsumen juga berhubungan positif dengan ekuitas merek yang dibuktikan dalam karya-karya sebelumnya (Yoo et al. dalam Gil, et al., 2007).

Promosi harga juga dapat mempengaruhi ekuitas merek. Seperti yang dijelaskan dalam Selvakumar dan Vikkraman (2011) bahwa promosi penjualan secara umum, dan promosi harga secara khusus dapat mempengaruhi keputusan jangka pendek konsumen untuk melakukan pembelian, akan tetapi dalam pengaruhnya pada ekuitas merek, promosi harga dapat melemahkan ekuitas merek. Secara keseluruhan, efek jangka panjang promosi harga dapat berdampak negatif pada persepsi kualitas pelanggan sehingga dapat berpengaruh pada ekuitas merek.

Iklan, harga, dan promosi harga memang merupakan tiga elemen pemasaran yang memberikan pengaruh pada ekuitas merek, namun dalam Gil, et al. (2007) dinyatakan pula bahwa keluarga juga memberikan pengaruh kuat dalam perilaku konsumen. Keluarga dapat memiliki pengaruh yang besar terhadap hubungan antara konsumen dengan merek, yang dapat mengakibatkan pembentukan ekuitas merek berbasis konsumen. Relevansi keluarga dalam pembentukan ekuitas merek adalah orang yang harus menghadapi situasi pembelian baru, dan tidak memiliki pengalaman konsumsi akan beralih ke keluarga sebagai pemberi saran ketika membeli suatu produk, mengingat bahwa mereka menganggap orang tua sebagai referensi terdekat yang dapat diandalkan.

\section{Ekuitas Merek}

Menurut Aaker dalam Durianto, et al. (2001:4), ekuitas merek adalah serangkaian aset dan liabilitas merek yang terkait dengan suatu merek, nama, simbol, yang mampu menambah atau mengurangi nilai yang diberikan sebuah produk atau jasa baik pada perusahaan maupun pada pelanggan. Kotler dan Armstrong (2004:292) dalam mendefinisikan ekuitas merek menyatakan bahwa ekuitas merek adalah efek diferensiasi positif yang dapat diketahui dari respons konsumen terhadap 
barang atau jasa. Dari definisi yang ada, dapat diketahui bahwa ekuitas merek adalah kekuatan suatu merek yang mampu menambah atau mengurangi nilai yang diberikan sebuah produk atau jasa baik pada perusahaan maupun pada pelanggan dan dapat diketahui dari respons konsumen terhadap barang atau jasa yang dijual.

Menurut Aaker dalam Durianto, et al. (2001:4), ekuitas merek dapat dikelompokkan ke dalam lima kategori, antara lain sebagai berikut:

1. Kesadaran merek (brand awareness) - menunjukkan kesanggupan seorang calon pembeli untuk mengenali atau mengingat kembali bahwa suatu merek merupakan bagian dari kategori produk tertentu.

2. Asosiasi merek (brand association) - mencerminkan pencitraan suatu merek terhadap kesan tertentu dalam kaitannya dengan kebiasaan, gaya hidup, manfaat, atribut produk, geografis, harga, pesaing, selebritis.

3. Persepsi kualitas (perceived quality) - mencerminkan persepsi pelanggan terhadap keseluruhan kualitas atau keunggulan suatu produk atau jasa layanan berkenaan dengan maksud yang diharapkan.

4. Loyalitas merek (brand loyalty) - mencerminkan tingkat keterikatan konsumen dengan suatu merek produk.

5. Aset-aset merek lainnya (other proprietary brand assets).

\section{Hipotesis Penelitian}

HIa : Belanja iklan suatu merek yang dirasakan oleh kalangan muda berpengaruh positif terhadap kesadaran merek.

H1b :Informasi merek positif yang diberikan oleh keluarga dari kalangan muda berpengaruh positif terhadap kesadaran merek.

H2a : Belanja iklan suatu merek yang dirasakan oleh kalangan muda berpengaruh positif terhadap asosiasi merek.

$\mathrm{H} 2 \mathrm{~b}$ : Informasi merek positif yang diberikan oleh keluarga dari kalangan muda berpengaruh positif terhadap asosiasi merek.

H3a : Belanja iklan suatu merek yang dirasakan kalangan muda berpengaruh positif terhadap persepsi kualitas merek. 
$\mathrm{H} 3 \mathrm{~b}$ : Informasi merek positif yang diberikan oleh keluarga dari kalangan muda berpengaruh positif terhadap persepsi kualitas.

H3c : Harga dari merek yang dirasakan oleh kalangan muda berpengaruh positif terhadap persepsi kualitas merek.

H3d : Promosi harga yang dirasakan semakin sering oleh kalangan muda berpengaruh negatif terhadap persepsi kualitas merek.

$\mathrm{H} 4 \mathrm{a}$ :Kesadaran merek berpengaruh secara langsung dan tidak langsung pada ekuitas merek melalui loyalitas merek sebagai variabel pemediasi.

$\mathrm{H} 4 \mathrm{~b}$ : Asosiasi merek berpengaruh secara langsung dan tidak langsung pada ekuitas merek melalui loyalitas merek sebagai variabel pemediasi.

H4c : Persepsi kualitas berpengaruh secara langsung dan tidak langsung pada ekuitas merek melalui loyalitas merek sebagai variabel pemediasi.

H5 : Loyalitas merek berpengaruh positif pada ekuitas merek.

\section{Metode Penelitian}

Mahasiswa akan menjadi subjek dari penelitian ini, dan objek penelitian ini adalah ekuitas merek dari Samsung Galaxy yang berbasis android serta pengaruhnya terhadap kepuasan konsumen. Populasi dalam penelitian ini adalah kalangan anak muda yang menggunakan Samsung Galaxy. Sampel penelitian akan didistribusikan sebanyak 200 eksemplar. Teknik pengambilan sampel yang digunakan adalah teknik non probability sampling dengan metode purposive sampling. Variabel dalam penelitian telah diuji diuji dengan teknik analisis Koefisien Korelasi Product Moment Pearson dan Cronbach Alpha, hasilnya dinyatakan valid dan reliabel.

Metode analisis data menggunakan regresi linier berganda, dan untuk menguji variabel mediasi menggunakan dua cara, cara pertama yaitu menggunakan penghitungan manual melalui uji regresi linier sederhana dan uji regresi linier berganda. Cara kedua menggunakan pengujian Preacher and Hayes's Script untuk menghitung efeknya. Berikut adalah tahapan untuk membantu menjelaskan berdasarkan pemahaman dari Zhao, et al. (2010). 


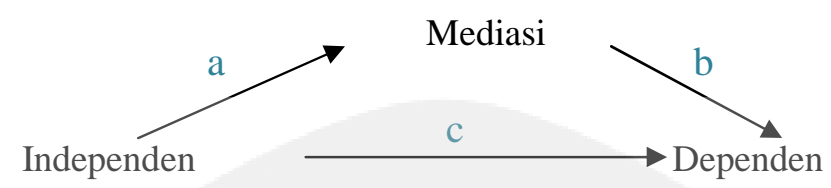

Gambar 1

Model Mediasi

Sumber: Zhao, et al. (2010).

Bagan akan membantu menjelaskan pemahaman mengenai mediasi:

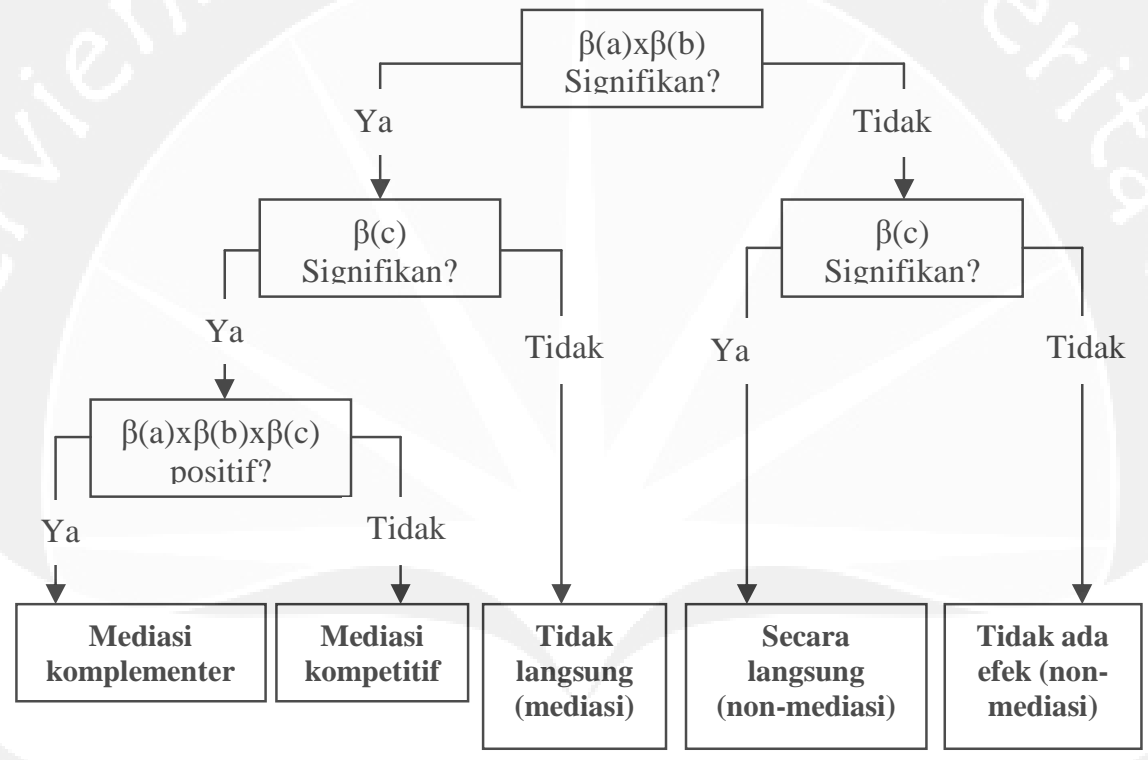

Gambar 2

Klasifikasi Tipe Mediasi

Sumber: Zhao, et al. 2010:201

\section{Hasil}

\section{Uji Regresi Linier Berganda}

Regresi Linier Berganda akan dilakukan sebanyak 5 kali yang dijabarkan sebagai berikut:

a. Pengujian untuk variabel dependen kesadaran merek dengan menguji H1a yaitu belanja iklan suatu merek yang dirasakan oleh kalangan muda berpengaruh positif 
terhadap kesadaran merek, dan H1b yaitu informasi merek positif yang diberikan oleh keluarga dari kalangan muda berpengaruh positif terhadap kesadaran merek. Hasil pengujian membuktikan bahwa H1a terbukti, yaitu belanja iklan suatu merek yang dirasakan oleh kalangan muda berpengaruh positif terhadap kesadaran merek, dan $\mathrm{H} 1 \mathrm{~b}$ terbukti yaitu informasi merek positif yang diberikan oleh keluarga dari kalangan muda berpengaruh positif terhadap kesadaran merek.

b. Pengujian untuk variabel dependen asosiasi merek dengan menguji $\mathrm{H} 2 \mathrm{a}$ yaitu belanja iklan suatu merek yang dirasakan oleh kalangan muda berpengaruh positif terhadap asosiasi merek, dan $\mathrm{H} 2 \mathrm{~b}$ yaitu informasi merek positif yang diberikan oleh keluarga dari kalangan muda berpengaruh positif terhadap asosiasi merek. Hasil pengujian membuktikan bahwa H2a tidak terbukti, yaitu belanja iklan suatu merek yang dirasakan oleh kalangan muda tidak berpengaruh positif terhadap asosiasi merek, dan $\mathrm{H} 2 \mathrm{~b}$ terbukti yaitu informasi merek positif yang diberikan oleh keluarga dari kalangan muda berpengaruh positif terhadap asosiasi merek.

c. Pengujian untuk variabel dependen persepsi kualitas dengan menguji H3a yaitu belanja iklan suatu merek yang dirasakan oleh kalangan muda berpengaruh positif terhadap persepsi kualitas, H3b yaitu informasi merek positif yang diberikan oleh keluarga dari kalangan muda berpengaruh positif terhadap persepsi kualitas, H3c yaitu harga dari merek yang dirasakan oleh kalangan muda berpengaruh positif terhadap persepsi kualitas, dan H3d yaitu promosi harga yang dirasakan semakin sering oleh kalangan muda berpengaruh negatif terhadap persepsi kualitas merek. Hasil pengujian membuktikan bahwa $\mathrm{H} 3$ a terbukti, yaitu belanja iklan suatu merek yang dirasakan kalangan muda berpengaruh positif terhadap persepsi kualitas merek, H3b terbukti yaitu informasi merek positif yang diberikan oleh keluarga dari kalangan muda berpengaruh positif terhadap persepsi kualitas, H3c terbukti yaitu harga dari merek yang dirasakan oleh kalangan muda berpengaruh positif terhadap persepsi kualitas merek, namun $\mathrm{H} 3 \mathrm{~d}$ tidak terbukti yaitu promosi 
harga yang dirasakan semakin sering oleh kalangan muda tidak secara signifikan berpengaruh negatif terhadap persepsi kualitas merek.

d. Selanjutnya untuk analisis regresi linier berganda dengan menggunakan variabel pemediasi untuk menguji $\mathrm{H} 4 \mathrm{a}$ yaitu kesadaran merek berpengaruh secara langsung dan tidak langsung pada ekuitas merek melalui loyalitas merek sebagai variabel pemediasi, H4b yaitu asosiasi merek berpengaruh secara langsung dan tidak langsung pada ekuitas merek melalui loyalitas merek sebagai variabel pemediasi, dan $\mathrm{H} 4 \mathrm{c}$ persepsi kualitas berpengaruh secara langsung dan tidak langsung pada ekuitas merek melalui loyalitas merek sebagai variabel pemediasi akan dilakukan sebanyak dua kali dengan penjelasan sebagai berikut:

Pengujian untuk variabel loyalitas merek yang bertindak sebagai pemediasi, dalam pengujian regresi ini loyalitas merek akan bertindak sebagai variabel dependen dan kesadaran merek, asosiasi merek, dan persepsi kualitas sebagai variabel independen. Hasilnya menunjukkan kesadaran merek, asosiasi merek, dan persepsi kualitas berpengaruh secara signifikan terhadap loyalitas merek.

Selanjutnya pengujian untuk variabel dependen ekuitas merek dengan variabel independen kesadaran merek, asosiasi merek, dan persepsi kualitas. Hasilnya menunjukkan bahwa kesadaran merek, asosiasi merek, dan persepsi kualitas berpengaruh secara signifikan terhadap ekuitas merek.

\section{Uji Regresi Linier Sederhana}

Regresi Linier Sederhana digunakan untuk menguji pengaruh variabel independen yaitu loyalitas merek terhadap variabel dependen yaitu ekuitas merek. Hasil uji regresi linier sederhana membuktikan H5 yaitu loyalitas merek berpengaruh positif terhadap ekuitas merek. 


\section{Analisis Mediasi}

Analisis mediasi dapat dilakukan dengan penghitungan manual dari analisis regresi yang linier sederhana dan berganda yang telah dilakukan dengan melihat dari nilai standardized coefficients $(\beta)$ akan dijabarkan sebagai berikut:

Tabel 1

Hasil Mediasi

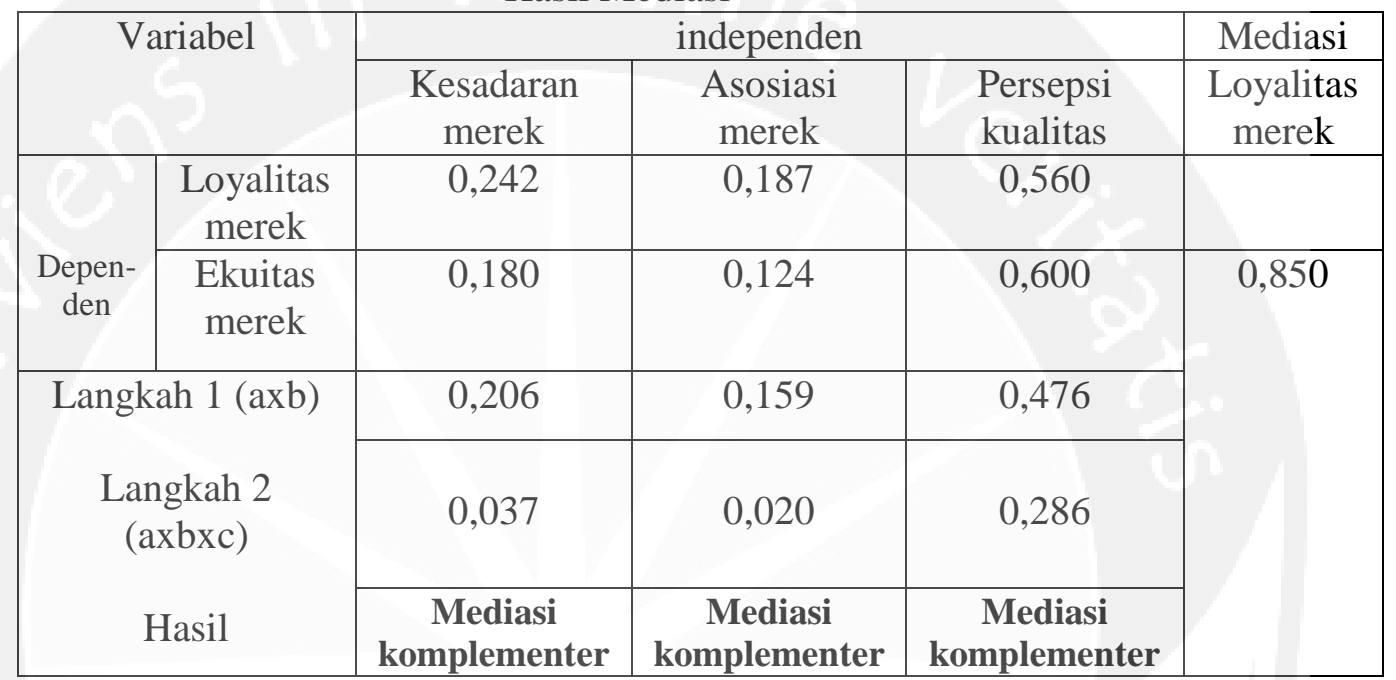

Sumber: Pengolahan data primer (2014)

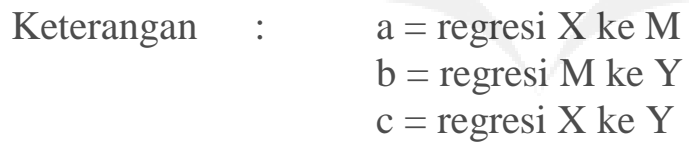

Selain itu dapat juga dilakukan dengan melakukan pengujian Preacher and Hayes's Script untuk menghitung efeknya, dan hasilnya menunjukkan bahwa kesadaran merek, asosiasi merek, dan persepsi kualitas signifikan secara langsung maupun tidak langsung melalui loyalitas merek terhadap ekuitas merek dan hubungan mediasinya disebut mediasi komplementer. Hasil tersebut membuktikan H4a yaitu kesadaran merek berpengaruh secara langsung dan tidak langsung pada ekuitas merek melalui loyalitas merek sebagai variabel pemediasi, H4b yaitu asosiasi merek berpengaruh secara langsung dan tidak langsung pada ekuitas merek melalui loyalitas merek sebagai variabel pemediasi, dan $\mathrm{H} 4 \mathrm{c}$ yaitu persepsi kualitas berpengaruh secara 
langsung dan tidak langsung pada ekuitas merek melalui loyalitas merek sebagai variabel pemediasi.

Berikut adalah hasil gabungan hasil signifikansi variabel-variabel dalam penelitian ini:

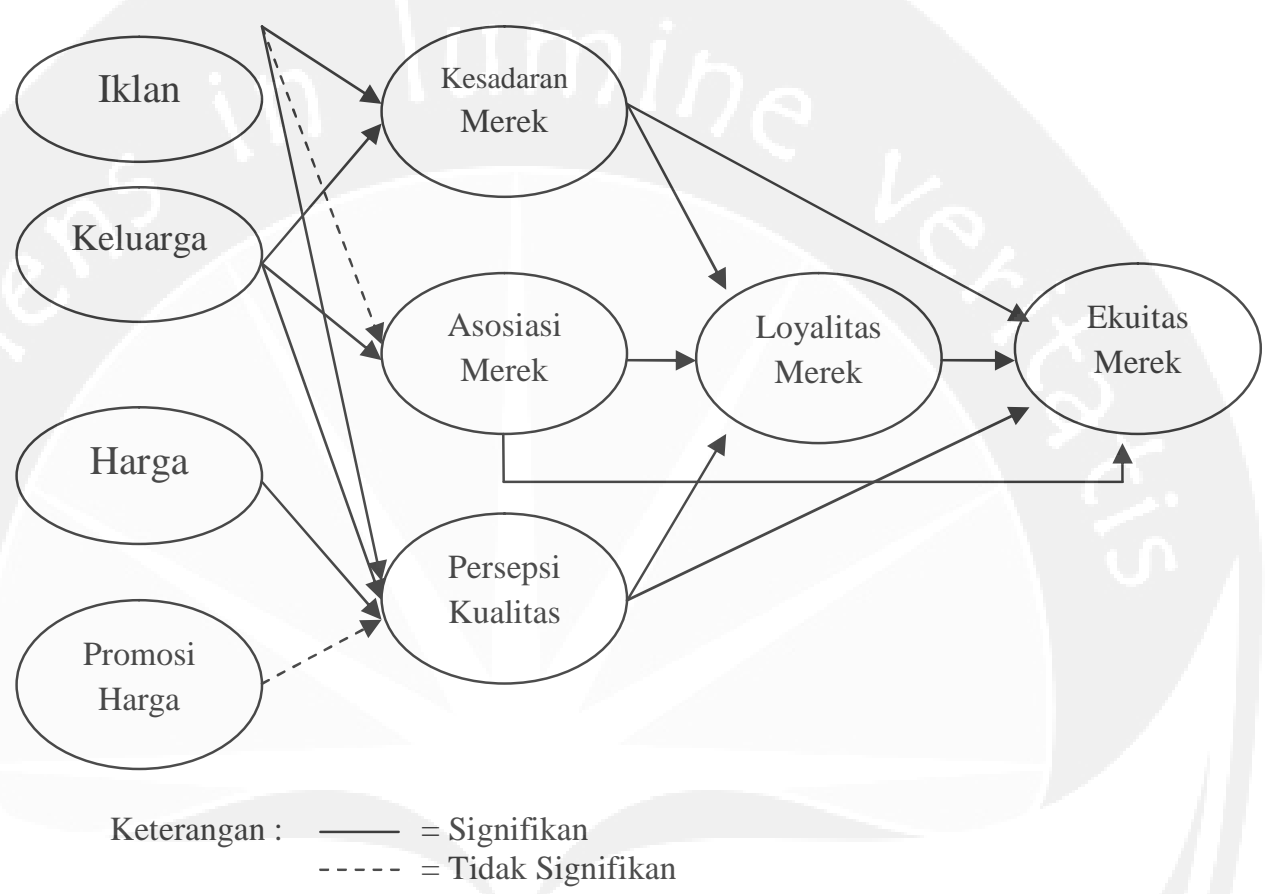

Gambar 3

Hasil Signifikansi Penelitian Sumber: Pengolahan Data Primer (2014)

Berdasarkan hasil penelitian yang ada, kesadaran merek Samsung Galaxy yang tercipta di benak konsumen dipengaruhi oleh banyaknya belanja iklan yang dirasakan oleh kalangan muda, dan informasi merek positif yang diberikan oleh keluarga dari kalangan muda (dalam penelitian ini kalangan muda adalah mahasiswa). Semakin tinggi biaya belanja iklan yang dirasakan (dengan seringnya diterpa oleh iklan Samsung Galaxy, dirasakan lebih sering beriklan dibandingkan kompetitor) dan semakin bagus informasi yang diberikan oleh keluarga mengenai Samsung Galaxy (ditunjukkan dari contoh yang diberikan orang tua/ keluarga dengan memakai Samsung Galaxy, memberikan pendapat yang baik dan rekomendasi 
tentang merek Samsung Galaxy), maka semakin tinggi pula kesadaran mereknya. Kesadaran merek yang kuat ditandai dengan ingatan yang kuat tentang merek Samsung Galaxy sebagai smarphone, kemampuan untuk mengenali dan menyebutkan tipe/seri dari Samsung Galaxy.

Asosiasi merek dalam penelitian ini dipengaruhi oleh informasi merek positif yang diberikan oleh keluarga, semakin bagus informasi yang diberikan mengenai merek Samsung Galaxy maka semakin bagus pula asosiasi yang terkait dengan merek Samsung Galaxy. Asosiasi merek dalam hasil penelitian ini terbukti tidak dipengaruhi oleh belanja iklan suatu merek yang dirasakan, kenyataannya semakin tinggi belanja iklan suatu merek yang dirasakan tidak terbukti membentuk asosiasi merek yang positif terkait Samsung Galaxy. Konsumen yang merasa bahwa belanja iklan Samsung Galaxy tinggi, tidak kemudian mengasosiasikan Samsung Galaxy lebih dapat dipercaya, ataupun memliki nilai lebih yang menjadikannya berbeda dengan kompetitor, karena kalangan muda lebih percaya dengan informasi positif yang diberikan oleh keluarga dibandingkan apa yang disajikan melalui iklan Samsung Galaxy.

Sementara untuk persepsi kualitas, berdasarkan hasil penelitian ini terbukti dipengaruhi oleh belanja iklan suatu merek yang dirasakan, informasi merek positif yang diberikan oleh keluarga, dan harga dari merek yang dirasakan. Tingginya belanja iklan dianggap oleh responden dalam penelitian ini sebagai tolok ukur persepsi kualitas, karena semakin banyak belanja iklan yang dikeluarkan berarti semakin terkenal dan berkualitas suatu merek tersebut. Informasi positif dari keluarga juga sangat berperan dalam mempengaruhi persepsi mengenai kualitas, semakin positif informasi yang diberikan mengenai merek Samsung Galaxy, maka kualitasnya akan dipersepsikan semakin tinggi. Harga suatu merek ternyata juga menjadi tolok ukur dari persepsi kualitas, bahwa jika dirasa harga Samsung Galaxy mahal, dan semakin tinggi melebihi kompetitor lainnya, maka kualitasnya akan dipersepsikan semakin bagus. Hal ini sesuai dengan Milgrom et al. dalam Gil, et al. (2007) yang 
menyatakan bahwa harga juga dianggap sebagai sinyal kualitas, merek dengan harga tinggi umumnya dianggap sebagai merek dengan kualitas yang lebih tinggi daripada yang memiliki harga rendah. Sementara promosi harga ternyata tidak memberikan pengaruh terhadap persepsi kualitas dalam penelitian ini. Promosi harga yang semakin sering dirasakan memang dapat mengikis persepsi mengenai kualitas menurut pendapat Suri et al. dalam Gil, et al. (2007), namun dalam penelitian ini promosi harga tidak mengakibatkan persepsi kualitas terhadap merek menjadi rendah, hal ini disebabkan karena variabel yang lain yaitu belanja iklan yang dirasakan, informasi positif yang diberikan keluarga, dan tingginya harga yang dipersepsikan lebih dominan membentuk persepsi kualitas dibandingkan promosi harga. Selain itu, variabel harga juga berperan membentuk persepsi kualitas, jadi walaupun dilakukan promosi harga, tapi harga asli yang sudah dirasa tinggi telah membentuk persepsi kualitas yang tinggi. Samsung Galaxy dipersepsikan sebagai produk yang berkualitas tinggi dan bagus, serta mengikuti perkembangan teknologi dan mencerminkan status sosial.

Penelitian ini membuktikan bahwa loyalitas merek dipengaruhi oleh kesadaran merek, asosiasi merek, dan ekuitas merek. Semakin tinggi kesadaran merek Samsung Galaxy mengenai suatu merek, ditambah dengan asosiasi yang sudah terbentuk adalah positif dan kualitas merek Samsung Galaxy dipersepsikan bagus pula, maka loyalitas terhadap merek Samsung Galaxy akan terbentuk. Dalam penelitian ini juga dibuktikan bahwa kesadaran merek, asosiasi merek, dan persepsi kualitas berpengaruh secara tidak langsung melalui loyalitas sebagai pemediasi komplementer terhadap ekuitas merek. Loyalitas terhadap merek Samsung Galaxy ditunjukkan dengan selalu menjadikan Samsung Galaxy sebagai pilihan pertama, loyal terhadap merek, dan rasa puas terhadap merek sehingga akan merekomendasikan merek Samsung Galaxy.

Semakin tinggi loyalitas terhadap suatu merek, maka semakin tinggi pula ekuitas mereknya. Gil, et al. (2007) dalam penelitiannya menyatakan bahwa 
kesadaran merek, asosiasi merek, dan persepsi kualitas tidak berpengaruh dalam membentuk ekuitas merek, dan yang berpengaruh pada ekuitas merek adalah loyalitas merek. Berbeda dengan temuan Gil, et al. (2007), ekuitas merek dalam penelitian ini selain dipengaruhi oleh loyalitas, juga dipengaruhi oleh kesadaran merek, asosiasi merek, dan persepsi kualitas. Semakin tinggi kesadaran merek, semakin positif asosiasi terkait merek, semakin positif persepsi terkait kualitas merek akan membuat loyalitas terhadap merek semakin kuat dan keempatnya akan membentuk ekuitas merek yang kuat. Ekuitas merek yang kuat ditandai dengan kesetiaan terhadap produk merek tertentu, dalam hal ini adalah Samsung Galaxy.

\section{Kesimpulan}

Kesimpulan yang dapat ditarik dari hasil analisis data dalam penelitian ini yaitu bahwa kesadaran merek dibentuk oleh belanja iklan yang dirasakan oleh kalangan muda, dan informasi positif mengenai merek yang diberikan keluarga. Informasi positif mengenai merek yang diberikan oleh keluarga juga membentuk asosiasi merek yang positif, sementara berlanja iklan yang dirasakan oleh kalangan muda tidak berperan membentuk asosiasi merek. Belanja iklan yang dirasakan oleh kalangan muda, informasi positif terkait merek yang diberikan oleh keluarga, dan harga suatu merek menjadi tolok ukur persepsi kualitas merek, sementara promosi harga tidak berpengaruh pada persepsi kualitas merek.

Kesadaran merek, asosiasi merek, dan persepsi kualitas akan membentuk loyalitas merek yang bertindak sebagai pemediasi dari kesadaran merek, asosiasi merek, dan persepsi kualitas. Loyalitas yang kuat terhadap merek ditunjukkan dengan selalu menjadikan merek tertentu sebagai pilihan pertama, loyal terhadap merek, dan rasa puas terhadap merek sehingga akan merekomendasikannya. Selain itu, kesadaran merek, asosiasi merek, persepsi kualitas, dan loyalitas merek juga berpengaruh secara langsung dalam membentuk ekuitas merek. Semakin tinggi kesadaran merek, asosiasi merek, dan persepsi kualitas serta loyalitas merek, maka akan semakin tinggi pula ekuitas mereknya yang ditandai dengan kesetiaan terhadap merek. 
Seringnya promosi harga dalam penelitian ini tidak terbukti berpengaruh secara signifikan mengikis persepsi kualitas, karena peran belanja iklan yang dirasakan oleh kalangan muda, informasi merek positif yang diberikan oleh keluarga, dan harga yang dirasakan oleh kalangan muda lebih dominan dalam membentuk persepsi kualitas.

\section{Referensi:}

Aaker, David A., 1997. Manajemen Ekuitas Merek. Terjemahan. Jakarta: Mitra Utama.

Durianto, Darmadi, Sugiarto, dan Toni Sitinjak. 2001. Strategi Menaklukan Pasar Melalui Riset Ekuitas dan Perilaku Merek. Jakarta: PT. Gramedia Pustaka Utama.

Gil, R. Bravo; Andres, E. Fraj; \& Salinas, E. Martines. 2007. Family as a Source of Consumer-based Brand Equity, Journal of Product \& Brand Management, 2007, Vol. 16, No 3, p. 188-199.

Kotler, Philip dan Gary Armstrong. 2004. Principle of Marketing. $10^{\text {th }}$ Edition/International Edition. New Jersey: Prentice Hall.

Kotler, Philip dan Keller, Kevin Lane. 2012. Marketing Management. 14 ${ }^{\text {th }}$ Edition/ Global Edition. United States: Pearson Education Limited.

Selvakumar, J. Joshua; \& Vikkraman, P. 2011. Impact of Advertising and Price Promotions on Brand Equity in Service Sector, Journal of Contemporary Research in Management, July-December 2011, p. 51-65.

Zhao, Xinshu; Lynch Jr,, John G; \& Chen, Qimei. 2010. Reconsidering Baron and Kenny : Myths and Truths about Mediation Analysis, Journal of Consumer Research, August 2010, Vol. 37, p. 197-206. 